\title{
El Salvador: Report on the Observance of Standards and Codes- Fiscal Transparency Module
}

This Report on the Observance of Standards and Codes on Fiscal Transparency for El Salvador was prepared by a staff team of the International Monetary Fund as background documentation for the periodic consultation with the member country. It is based on the information available at the time it was completed on December 29, 2004. The views expressed in this document are those of the staff team and do not necessarily reflect the views of the government of El Salvador or the Executive Board of the IMF.

The policy of publication of staff reports and other documents by the IMF allows for the deletion of market-sensitive information.

To assist the IMF in evaluating the publication policy, reader comments are invited and may be sent by e-mail to publicationpolicy@imf.org.

Copies of this report are available to the public from

International Monetary Fund • Publication Services

700 19th Street, N.W. • Washington, D.C. 20431

Telephone: (202) 6237430 • Telefax: (202) 6237201

E-mail: publications@imf.org • Internet: http://www.imf.org

Price: $\$ 15.00$ a copy

\section{International Monetary Fund \\ Washington, D.C.}





\title{
INTERNATIONAL MONETARY FUND
}

\author{
EL SALVADOR
Report on the Observance of Standards and Codes (ROSC) Fiscal Transparency Module

\author{
Prepared by the Fiscal Affairs Department
}

Approved by Anoop Singh and Teresa Ter-Minassian

December 29, 2004

\section{EXECUTIVE SUMMARY}

El Salvador complies with many of the standards contained in the Code of Good Practices on Fiscal Transparency. The definition of the government sector is consistent with the norms established in the Government Finance Statistics (GFS) Manual; relations between the government and the rest of the public sector have been substantially clarified; privatizations have been subjected to independent audits; the regulatory framework for fiscal management is complete; the annual general state budget (Presupuesto General del Estado (PGE)) and budgetary execution reports encompass practically the entire nonfinancial public sector; systems of internal control are subject to effective audits; full information is published on the level and composition of the public debt; the Integrated Financial Management System (Sistema de Administración Financiera Integrado (SAFI)) includes an integrated accounting system that makes it possible to evaluate payment arrears, generate timely budgetary execution reports and reconcile monetary and accounting data on a routine basis; and significant transparency requirements have been built into public contracting. In addition, El Salvador subscribes to the Special Data Dissemination Standard (SDDS) and provides information to the GFS Yearbook. Nonetheless, progress still is needed in clarifying intergovernmental fiscal relations; expanding and improving the content of budget documentation; redefining and strengthening oversight systems; and strengthening budget preparation.

In the short term, the authorities could make substantial progress on fiscal transparency, as follows:

(i) strengthening the budget presentation by including a consolidation of central government consistent with the GFS; providing summary tables showing the derivation of the budget balance from the main fiscal aggregates and its financing; and an annex containing medium-term fiscal policy objectives and priorities; and (ii) by publishing existing monthly, quarterly, and biannual reports on the execution of the PGE and on the financial situation of the nonfinancial public sector (NFPS).

Additional improvements could be introduced in the medium term, by: (i) clarifying intergovernmental fiscal relations between the central government and municipalities; (ii) extending SAFI to decentralized public institutions (DPIs) and subsequently to the municipalities; (iii) including estimates of quasi-fiscal activities, fiscal risks and tax expenditures in budget documentation; (iv) preparing a multiyear expenditure framework to serve as a basis for preparing the budget; (v) introducing a functional classification; (vi) carrying out performance audits and making their conclusions and recommendations public; and (vii) enhancing private sector regulations. 


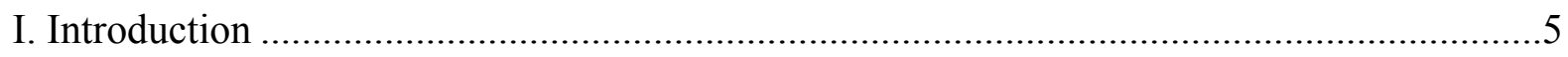

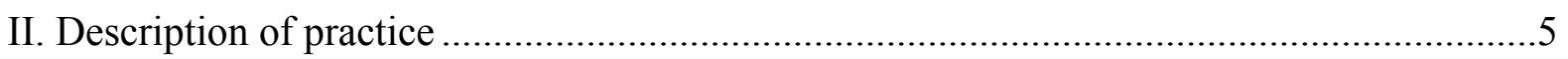

A. Clarity of roles and responsibilities ....................................................................

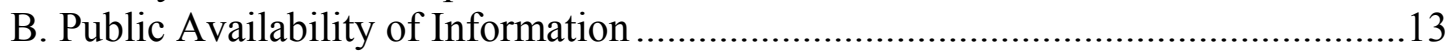

C. Open Budget Preparation, Execution, and Reporting ............................................16

D. Assurances of integrity ................................................................................... 18

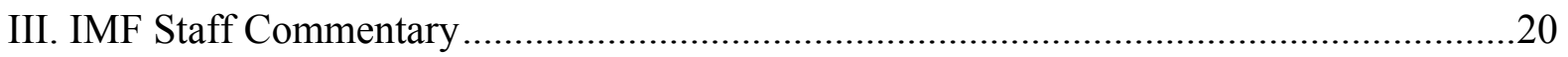




\section{DoCUMENTS AND InSTITUTIONS: ACRONYMS AND WEBSITES}

\begin{tabular}{|c|c|c|c|}
\hline ANDA & $\begin{array}{l}\text { National Water and Sewerage } \\
\text { Administration }\end{array}$ & $\begin{array}{l}\text { Administración Nacional de } \\
\text { Acueductos y Alcantarillado }\end{array}$ & \\
\hline ANTEL & $\begin{array}{l}\text { National Administration } \\
\text { Telecommunications }\end{array}$ & $\begin{array}{l}\text { Administración Nacional de } \\
\text { Telecomunicaciones }\end{array}$ & \\
\hline BCR & $\begin{array}{l}\text { Central Reserve Bank of El } \\
\text { Salvador }\end{array}$ & $\begin{array}{l}\text { Banco Central de Reserva de } \\
\text { El Salvador }\end{array}$ & http://www.bcr.gob.sv \\
\hline BFA & Agricultural Development Bank & Banco de Fomento Agropecuario & \\
\hline BHS & Mortgage Bank of El Salvador & Banco Hipotecario de El Salvador & \\
\hline BMI & Multisectoral Investment Bank & Banco Multisectorial de Inversiones & http://www.bmi.gob.sv \\
\hline CCR & $\begin{array}{l}\text { Comptroller General of the } \\
\text { Republic }\end{array}$ & Corte de Cuentas de la República & http://www.cortedecuentas.gob.sv \\
\hline CEL & $\begin{array}{l}\text { Lempa River Hydroelectric Power } \\
\text { Commission }\end{array}$ & $\begin{array}{l}\text { Comisión Ejecutiva Hidroeléctrica } \\
\text { del Rio Lempa }\end{array}$ & http://www.cel.gob.sv \\
\hline CEPA & Autonomous Port Authority & $\begin{array}{l}\text { Comisión Ejecutiva Portuaria } \\
\text { Autónoma }\end{array}$ & http://www.cepa.gob.sv \\
\hline CORPSAIN & $\begin{array}{l}\text { Salvadoran Investment } \\
\text { Corporation }\end{array}$ & $\begin{array}{l}\text { Corporación Salvadoreña de } \\
\text { Inversiones }\end{array}$ & \\
\hline DGII & $\begin{array}{l}\text { Directorate General of Domestic } \\
\text { Taxation }\end{array}$ & $\begin{array}{l}\text { Dirección General de Impuestos } \\
\text { Internos }\end{array}$ & $\frac{\text { http://www.mh.gob.sv/se/sce/listado }}{. j \mathrm{sp}}$ \\
\hline DL & Decree Law & Decreto-Ley & http://www.cortedecuentas.gob.sv \\
\hline DPI & Decentralized public institutions & $\begin{array}{l}\text { Instituciones públicas } \\
\text { descentralizadas }\end{array}$ & $\begin{array}{l}\text { http://www.gobernacion.gob.sv/eGo } \\
\text { bierno/Direcciones/Descentralizadas }\end{array}$ \\
\hline FAD & Fiscal Affairs Department & & \\
\hline FEAGIN & $\begin{array}{l}\text { Special trust fund for persons } \\
\text { affected by illegal operations of } \\
\text { the INSEPRO group }\end{array}$ & $\begin{array}{l}\text { Fondo fiduciario especial para } \\
\text { atender a los afectados de las } \\
\text { operaciones ilegales realizadas por } \\
\text { el grupo INSEPRO }\end{array}$ & $\begin{array}{l}\text { http://www.ssf.gob.sv/frm informac } \\
\text { ion/frm informacion.htm }\end{array}$ \\
\hline FIGAPE & $\begin{array}{l}\text { Small business financing and } \\
\text { guarantee fund }\end{array}$ & $\begin{array}{l}\text { Fondo de financiamiento y garantía } \\
\text { para la pequeña empresa }\end{array}$ & \\
\hline FODES & $\begin{array}{l}\text { Economic and social development } \\
\text { fund }\end{array}$ & $\begin{array}{l}\text { Fondo para el desarrollo económico } \\
\text { y social de los municipios }\end{array}$ & http://www.isdem.gob.sv \\
\hline FONAVIPO & National popular housing fund & Fondo nacional de vivienda popular & $\underline{\text { www.fonavipo.gob.sv }}$ \\
\hline FOSAFFI & $\begin{array}{l}\text { Financial strengthening and } \\
\text { restructuring fund }\end{array}$ & $\begin{array}{l}\text { Fondo de saneamiento y } \\
\text { fortalecimiento financiero }\end{array}$ & www.ssf.gob.sv \\
\hline $\begin{array}{l}\text { FOSOFAMILI } \\
\text { A }\end{array}$ & $\begin{array}{l}\text { Family microenterprise solidarity } \\
\text { fund }\end{array}$ & $\begin{array}{l}\text { Fondo solidario para la familia } \\
\text { microempresaria }\end{array}$ & www.fosofamilia.gob.sv \\
\hline FSV & Social housing fund & Fondo social para la vivienda & www.fsv.gob.sv \\
\hline GFSM & $\begin{array}{l}\text { Government Finance Statistics } \\
\text { Manual } 2001\end{array}$ & $\begin{array}{l}\text { Manual del Sistema de Contabilidad } \\
\text { Gubernamental } 2001\end{array}$ & \\
\hline IPSFA & $\begin{array}{l}\text { Armed Forces Social Security } \\
\text { Institute }\end{array}$ & $\begin{array}{l}\text { Instituto de Previsión Social de las } \\
\text { Fuerzas Armadas }\end{array}$ & http://www.ipsfa.com/main.htm \\
\hline LOAFI & State Financial Management Act & $\begin{array}{l}\text { Ley Orgánica de Administración } \\
\text { Financiera del Estado }\end{array}$ & \\
\hline MOF & Ministry of finance & Ministerio de Hacienda & http://www.mh.gob.sv \\
\hline NFPEs & Nonfinancial public enterprises & Empresas públicas no financieras & \\
\hline NFPS & Nonfinancial public sector & Sector público no financiero & \\
\hline PGE & General State Budget & Presupuesto General del Estado & $\begin{array}{l}\text { http://www.mh.gob.sv/mh_2003/pre } \\
\text { supuesto.htm }\end{array}$ \\
\hline ROSC & Reports on Observance of & Reporte sobre el Cumplimiento de & \\
\hline
\end{tabular}




\section{DoCUMENTS AND InSTITUTIONS: ACRONYMS AND WEBSITES}

\author{
Standards and Codes \\ Integrated financial management \\ system \\ Special Data Dissemination \\ Standard
}

Reglas y Estándares

Sistema de Administración

Financiera Integrado

Estándar para la Difusión de Datos

Especiales http://www.mh.gob.sv/mh_2003/cir

culares/safi/acuerdo1355.pdf

\section{El Salvador: Basic Data}

Type of government: Republic

Fiscal year: Calendar

Population: 6.6 million (estimate)

GDP (2004): US\$15.9 billion (estimate)

Debt/GDP (2004): 43.3 percent of GDP (estimate) 


\section{INTRODUCTION ${ }^{1}$}

1. This report provides an assessment of fiscal transparency practices in El Salvador, comparing them with the requirements of the IMF Code of Good Practices on Fiscal Transparency. The assessment has two parts. The first contains a description of practice, prepared by IMF staff on the basis of consultations with the authorities, the authorities' response to the fiscal transparency questionnaire, and other available information. The second part is an IMF staff commentary on fiscal transparency in El Salvador.

\section{Description of Practice}

\section{A. Clarity of Roles and Responsibilities}

\section{Definition of government}

2. The general government sector is defined in accordance with the GFS Manual. Under the Constitution, ${ }^{2}$ the formulation and execution of public policies is the responsibility of the government, comprised of the legislature, the executive, the judiciary, a number of constitutional bodies, and local governments. The law regulates the composition and functions of the executive branch, on which ministries and decentralized public institutions (DPIs) depend. ${ }^{3}$ The relevant definition of government for budgetary and fiscal reporting purposes in El Salvador is the NFPS, which consists of the general government sector (central government, 62 nonentrepreneurial DPIs and 262 local governments), and four nonfinancial public enterprises (NFPEs). ${ }^{4}$

\footnotetext{
${ }^{1}$ Consultations on fiscal transparency in El Salvador were held by an IMF team, consisting of Ms. Guin-Siu and Mr. Viñuela-Díaz. They met with staff from the Technical Secretariat of the Office of the Presidency, the Ministries of Finance and Public Works, the Office of the Comptroller General of the Republic, the Central Reserve Bank, the DPIs, and private sector representatives.

${ }^{2}$ Constitution of 1983 (amended in 1991, 1994, and 1996). Title VI of the Constitution regulates the attributions and competencies of government bodies.

${ }^{3}$ The Internal Regulation of the Executive (Decree 24 of April 18, 1999) regulates ministerial functions. DPIs are institutions with legal status, their own assets and functional autonomy; each DPI has its own regulation. Most of them carry out noncommercial functions; they include the University of El Salvador, national hospitals, social security institutions and regulatory bodies. Expenditure by nonentrepreneurial DPI accounts for about one-third of total central government spending. Four entities are classified for budgetary purposes as NFPEs despite legally being DPIs, because they basically engage in commercial activities (Paragraph 6).

${ }^{4}$ The central government consists of the legislature (Legislative Assembly), the judiciary, 13 ministries, the public prosecutor's department (Fiscalía General de la República, Procuraduría General de la República, and Procuraduría para la Defensa de los Derechos Humanos) and other bodies: the Office of the Comptroller General of the Republic (Corte de Cuentas de la República), the Supreme Electoral Tribunal (Tribunal Supremo Electoral), the Civil Service Tribunal (Tribunal del Servicio Civil), and the National Judicial Council (Consejo Nacional de la Judicatura). It should be noted that by excluding nonentrepreneurial DPIs, this concept of central
} 


\section{Intergovernmental relations}

\section{Fiscal relations between central and local governments need further}

clarification. ${ }^{\mathbf{5}}$ Under the constitution, municipalities (municipios) have financial, technical, and administrative autonomy. The municipal code ${ }^{6}$ identifies, albeit not always very precisely, 27 areas of municipal jurisdiction in which the central government can only intervene when the local government fails to exercise its competencies or does so in a deficient manner. ${ }^{7}$ Even then, the central government must act with the consent of the municipal authorities and in coordination with their plans and programs. In practice, however, many of the competencies assigned to municipalities are shared with the central government, and there is no clear delineation of functions pertaining to each government level. Within certain limits, local governments can design and propose their own taxes, which are then approved by the legislative assembly. The General Taxation Act allows municipalities to set and approve their own fees and special charges in the framework of a general law. Local tax revenues represent a small share of the total revenues of municipalities. ${ }^{8}$ There are no legal limits or any reporting on municipal borrowing; municipalities require authorization to borrow only if they want to make use of a government guarantee.

\section{Municipalities finance their activities largely through earmarked transfers from the central government, which are distributed according to clear and stable principles. Nonetheless, the use of these resources is not transparent. Transfers are mainly channeled through the Economic and Social Development Fund (Fondo para el Desarrollo Económico $y$ Social de los Municipios (FODES)), which is envisaged in the constitution for the purpose of guaranteeing financial autonomy to the municipalities. Transfers from this fund are defined as a percentage of central government current revenues. This percentage was 6}

government is not strictly comparable with that proposed by the GFS Manual. In this report, the term "central government" will be used as it is used in El Salvador.

5 The main laws governing local fiscal activity are as follows: the Constitution (Articles 202-207); the Municipal Code (Decree 274 of January 31, 1986) which establishes general principles for the exercise of municipal autonomy, including those to be followed in municipal finance; and the General Taxation Act (Decree 86 of December 5, 1991) which defines the operating framework for municipalities on tax issues, regulates infractions and sanctions, and defines the faculties and procedures of local tax administration.

${ }^{6}$ Article 4.

${ }^{7}$ In addition to providing traditional local public services, this list contains a wide range of competencies on various sectors (promotion and financing of housing programs; promotion and development of health programs, environmental sanitation, and prevention and combat of diseases; preparation, approval and execution of urban and rural development plans, etc.). Local expenditure accounts for approximately 5 percent of general government expenditure.

${ }^{8}$ The share of local tax revenues in total municipal revenues was 21.3 percent in 2002 and 18.7 percent in 2003. 
percent until 2003, increased to 6.5 percent in 2004 and will reach 7 percent in $2005^{9}$; it is automatically distributed among the municipalities through a pre-established formula, and must be used basically for investment purposes. ${ }^{10}$ Nonetheless, the absence of a legal requirement obliging municipalities to provide information on the way they use these resources makes it impossible to know the extent to which the conditions are being complied with, or how a significant percentage of public revenues is being used.

\section{Demarcation of functions between branches of government}

\section{The fiscal roles of the legislative and executive branches of government are} clearly defined in the constitution and other laws. The executive is responsible for preparing the draft revenue and expenditure budget and submitting it to the legislative assembly at least three months before the new fiscal year begins. The legislature is responsible for amending it and approving it. ${ }^{11}$ It may reduce or reject appropriations requested, but never increase them. The president holds the right of veto on laws passed by the assembly, which can only be overturned by a two-third majority. The executive branch can transfer appropriations between budgetary items within a given sector of public administration, provided the corresponding appropriations are not classified as nontransferable. ${ }^{12}$ Transfers of appropriations between different sectors, and any increase (reduction) of the overall budgeted level of expenditure (revenue) must be approved by the legislative assembly, specifying the funding sources to be used for their financing or replacement.

\footnotetext{
${ }^{9}$ Decree 348 of June 17, 2004.

${ }^{10}$ Constitution, Article 207. The size of this fund, and criteria governing the distribution and use of its proceeds, are regulated in the act creating FODES (Decree 74 of September 8, 1998) and its regulation (Decree 35 of March 25, 1998). The variables and weightings used for distributing the fund are as follows: population (50 percent), equity ( 25 percent), poverty ( 20 percent) and geographic area ( 5 percent). Of resources thus obtained, 80 percent must be used for investments and 20 percent for current expenditure by each municipality. The fund is managed by the Salvadoran Municipal Development Institute (Decree 616 of March 4, 1987), an autonomous body that provides technical and financial assistance to the municipalities.

${ }^{11}$ Should the new budget fail to gain approval before the start of the fiscal year, the previous year's budget would be rolled over; once the new budget act is passed, adjustments would be made to take account of executions already carried out.

${ }^{12}$ Article 229 of the Constitution. The organic law on state financial management (LOAFI) establishes in Article 70 that budgetary appropriations voted for investment may not be used to cover current expenditure, except in cases authorized by the council of ministers and suggested by the minister of finance such as the counterpart resources and taxes generated by investments. Also considered nontransferable are appropriations for debt service and transfers between the appropriations of special budgets, name used in El Salvador for the budgets of nonentrepreneurial DPIs.
} 


\section{Relations between the government and the rest of the public sector}

\section{Privatization and reorganization processes have reduced the importance of} NFPEs in the public sector and have clarified their relations with the government. In El Salvador, NFPEs ${ }^{13}$ have traditionally been regulators and administrators of legal monopolies, and some of them have carried out significant quasi-fiscal activities. In 1998 and 1999 the telecommunications firm (Administración Nacional de Telecomunicaciones, (ANTEL)) was privatized, along with the thermal generation and some of the distribution arms of the electricity company, (Lempa River Hydroelectric Power Commission, Comisión Ejecutiva Hidroeléctrica del Rio Lempa (CEL)). Prior to this, regulatory and management functions had been separated, and both sectors were reorganized in order to free up entry and introduce competition. This has resulted in increased competition, lower utility charges and the suppression of quasi-fiscal activities. ${ }^{14}$ Privatization processes, legally regulated, have been subject to all kinds of guarantees and publicity in their design, tendering and award processes. Two of the three remaining NFPEs hold monopolies for water, port, airport and railroad services. Of these, only the water company carries out major quasi-fiscal activities. ${ }^{15}$

\section{The Central Reserve Bank of El Salvador (Banco Central de Reserva de} El Salvador (BCR) $)^{16}$ is legally independent of the government but carries out fiscal functions on the government's behalf. Formally, the BCR is a technically autonomous public institution. It is run by a board of governors whose president is appointed by the President of the Republic, and whose governors are appointed by the council of ministers. ${ }^{17}$ The BCR cannot finance the government or the rest of the public sector, either directly or indirectly, nor extend collateral, guarantees or sureties on obligations contracted by them, other than in exceptional circumstances which are legally identified and approved by the

\footnotetext{
${ }^{13}$ These enterprises are the water supply firm (Administración Nacional de Acueductos y Alcantarillado $(A N D A)), \mathrm{CEL}$, and the autonomous port authority (Comisión Ejecutiva Portuaria Autónoma (CEPA)). The category also includes the national lottery.

${ }^{14}$ The effect on competition and tariffs has been more pronounced in the telecommunications sector, where the public monopoly was restructured before privatization, making it possible to open up the sector from the outset. In contrast, electricity privatization, while equally transparent from the procedural standpoint, was based on closed contracts which, instead of openness, resulted in exclusivity.

${ }^{15}$ ANDA generates losses largely because the average tariff it charges is 25 percent lower than its unit cost.

16 The Organic Law of the BCR (Decree 746 of April 12, 1991) has been reformed on several occasions-most recently through the Monetary Integration Act (Decree 201 of November 30, 2000) which sets a fixed and unchangeable exchange rate between the colón and the U.S. dollar.

${ }^{17}$ Of the seven board members, three are proposed by the private sector, including one by banks and financial institutions (Article 10). Three years ago, the financial sector representative renounced this right.
} 
legislative assembly. ${ }^{18}$ Its services as government financial/fiscal agent and adviser are clearly regulated, but they are not provided under market conditions. ${ }^{19}$ The BCR undertakes significant quasi-fiscal activities, which undermine its net worth. ${ }^{20}$ Nonetheless, during the 1990s and up to 2001, the BCR has been able to absorb the impact of these operations and maintain a positive operating balance. At the present time its financial position is sound.

\section{Government activities are not always clearly distinguished from the activities of public financial institutions. The financial public sector consists of two banks which in 2001 accounted for 4.5 percent of the assets of the entire banking system: the Agricultural Development Bank (Banco de Fomento Agropecuario (BFA)) and the Mortgage Bank of El Salvador (Banco Hipotecario de El Salvador $(B H S))^{21}$ in addition to certain nonbank public financial institutions created for various purposes. ${ }^{22}$ In the last two years, both of these}

\footnotetext{
${ }^{18}$ In the event of war, invasion, rebellion, sedition, catastrophe, epidemic, or other general calamity or serious disturbance of public order.

${ }^{19}$ State funds have to be deposited in the single treasury account opened at the BCR. General account balances do not earn any interest; investment account balances earn a symbolic rate of interest. In exchange, the BCR does not charge commission on the services it provides, except for long-term placements.
}

${ }^{20}$ Until December 31, 2001, the state had debts with the BCR as a result of various situations that were not generating any return. On that date, those debts were consolidated, with authorization from the legislative assembly, in a single bond of US $\$ 704$ million paying the Libor rate plus $2 \frac{1}{2}$ percentage points. In addition, the $\mathrm{BCR}$ is the owner of the financial strengthening and restructuring fund (fondo de saneamiento y fortalecimiento financiero (FOSAFFI)); of 96 percent of the BHS through FOSAFFI; and of the Multisectoral Investment Bank (Banco Multisectorial de Inversiones (BMI)). These holdings earn a return well below market rates. In addition, the BCR is guarantor of trust fund certificates issued by the special trust fund for persons affected by illegal operations carried out by the INSEPRO group (fondo fiduciario especial para atender a los afectados de las operaciones ilegales realizadas por el grupo INSEPRO (FEAGIN)). The certificates that were sold to private banks earn interest rates of 4.5 percent (the market rate was fluctuating between 10 percent and 11 percent at the time). FEAGIN pays the interest but not the principal, which is included as a liability in the BCR balance sheet (in 2001, these liabilities amounted to US\$81.7 million). FOSAFFI and FEAGIN were created to address problems of bank restructuring.

${ }^{21}$ BFA is a credit DPI, while BHS is a mixed ownership enterprise. The latter is not audited by the Comptroller General of the Republic even though the state owns 96 percent of the equity. It is audited by the superintendence of the financial system, however.

${ }^{22}$ The social housing fund ((fondo social para la vivienda (FSV)), the national popular housing fund (fondo nacional de vivienda popular (FONAVIPO)), the BMI, the small business financing and guarantee fund (fondo de financiamiento y garantía para la pequeña empresa (FIGAPE)), the family microenterprise solidarity fund (fondo solidario para la familia microempresaria (FOSOFAMILIA)), the Salvadoran Investment Corporation (Corporación Salvadoreña de Inversiones (CORPSAIN)), the Armed Forces Social Security Institute (Instituto de Previsión Social de las Fuerzas Armadas (IPSFA)), FOSAFFI, and the FEAGIN (see footnote 20). Of these entities, the first six perform development functions, not always under market conditions; IPSFA is an armed forces social security organization, which is supervised by the superintendence of the financial system (since it grants loans to its affiliates) but not by the superintendence of pensions (although it should be, since it is a pension fund). All public financial institutions are regulated by the superintendence of the financial system. 
banks suffered losses as a result of the development activity that has been legally assigned to them. ${ }^{23}$ In addition to FOSAFFI and FEAGIN (see footnote 20), two other important nonbank public financial entities are the FSV and the BMI. The first of these is an autonomous official lending institution, which grants mortgage loans at subsidized interest rates to affiliates of the pension system (public or private); since 1998 its resources have basically come from pension funds. The other is a second-tier bank that channels funds to eligible credit institutions, essentially private banks, for the purpose of lending for private sector investment. ${ }^{24}$

\section{Relations between the central government and the private sector}

\section{Government equity ownership in nonbank private sector institutions is minimal,} and the regulations governing this sector are clear. Minor government shareholdings in the private sector are usually held indirectly through public enterprises, and are declared in the corresponding balance sheets and audit reports. Although there is no legally established procedure for the preparation or modification of private sector regulations, these are usually given a public hearing before approval.

\section{Legal framework for fiscal management}

\section{The legal and administrative framework for fiscal management is clear and}

complete. The constitution establishes the following rules: taxes can be imposed only by law; public funds can be committed only if an appropriation exists; all public revenue is channeled to a single fund that is generally available to meet state obligations; and the PGE contains an estimate of all expected revenues, together with authorization of all expenditure, for each fiscal year. ${ }^{25}$ The state financial management act (Ley Orgánica de Administración Financiera del Estado, (LOAFI)) and its regulations ${ }^{26}$ govern public sector financial management and establish the SAFI, covering budget, treasury, public debt, public investment, and government accounting systems. Each of these systems is managed by a general directorate of the ministry of finance (MOF), whose functions are clearly regulated. These rules make the minister of finance responsible for direction and coordination of public

\footnotetext{
${ }^{23}$ There is no quantitative estimate of the quasi-fiscal activities carried out by these institutions. Over the last decade, the government has transferred about US\$17 million on average per year to the BFA, and in 2000 it injected a further US\$45.7 million. The BHS has also been the subject of restructuring.

${ }^{24}$ The BMI, which is owned by the BCR, has been funded with contributions and loans from the latter up to 1999 , supplemented by resources provided by international financial institutions. The loans it extends are of low risk, since they are automatically recovered through the liquidity accounts that eligible banks hold at the BCR.

${ }^{25}$ The Constitution regulates public finance in Articles 223-234.

${ }^{26}$ Decree 526, of December 6, 1995; amended by Decrees 716, of May 23, 1996 and 172 of December 4, 1997; and Decree 82 of August 16, 1996, which approves the regulation.
} 
finances. They regulate the preparation, approval, execution, monitoring, and evaluation of the budget; cash management and the treasury single account; public investment and public debt; and the objectives, principles, and elements of the government accounting system. In addition, they create an institutional financial unit in each budgeted entity, responsible for financial management and for undertaking all activities relating to budget, treasury, and accounting. These units provide links to the MOF divisions responsible for each SAFI system, and they are required to comply with all the technical rules on financial management issued by the MOF. The legal framework for fiscal management is oriented toward fulfillment of financial objectives.

\section{Extrabudgetary activities}

\section{The mechanisms for coordination and management of budgetary and} extrabudgetary activities are well established. Extrabudgetary activities consist of resources not included in the PGE approved by the legislative assembly, although their management and accounting adhere to SAFI procedures and are included in the Public Finance Management Report (see Paragraph 19). ${ }^{27}$ These activities that represented 13.3 percent of total NFPS in 2003, escape scrutiny by the legislative assembly during the approval stage.

\section{Taxation}

\section{The tax system has an explicit legal basis, and the new tax code ${ }^{28}$ has} significantly reduced the level of discretion in the interpretation of tax laws. Taxes can be created, modified, exonerated, or suppressed only by law. Sanctions must also be established by law. All tax laws and regulations are published in the Official Gazette (Diario Oficial). The new tax code restricts the interpretation of tax laws and makes it easier for taxpayers to make their declarations electronically. Resolutions issued by the tax

\footnotetext{
${ }^{27}$ The main extrabudgetary activities are classified as "extraordinary resources," "special activity funds" and the budgets of autonomous bodies. "Extraordinary resources" consist of the economic recovery budget, the extraordinary institutional resources and the public investment budget. The first of these, approved for the first time in 1982, is financed each year by the Ministry of Foreign Affairs using external resources mainly from technical assistance and counterpart funds. The second, funded from transfers from the PGE, is used to develop electric infrastructure. The third, which was approved in late 2000 and has a life span running until 2003, is financed from the proceeds of the telecommunications privatization, for use in specific projects other than those already included in the PGE investment budget. Special activity funds are financed from revenues earned by budgetary entities from the sale of certain goods and services; they must be used for a specific pre-established purpose approved by the MOF. Finally, there are a number of DPIs, called autonomous institutions, whose charters exempt their budgets from legislative approval (for example, the Armed Forces Social Security Institute, the SFV, the Salvadoran Fund for Pre-investment Studies, the Military Hospital, and the Armed Forces Pharmaceutical Center). Their budgets are approved either by the government or by their board of directors.

${ }^{28}$ The Tax Code Decree Law (DL) 230 of December 14, 2000, and its regulation (DL 117 of December 11, 2001).
} 
administration can be appealed by the taxpayer before the appeals tribunal of the Directorate General of Internal Taxation (Dirección General de Impuestos Internos (DGII)); once the administrative channel has been exhausted, the latter's resolutions can be appealed before the Special Administrative Court (Jurisdicción Contencioso-Administrativa). There are few value-added tax (VAT) exemptions, but the evasion rate on this tax is relatively high. ${ }^{29}$ There are no ethical codes for tax administration employees.

\section{The civil service}

\section{The criteria used to select and promote civil servants are discretionary, and} there is wide variation in wage policy and job stability among different public sector employees. Pay and conditions in public sector employment are governed by the civil service act, the wages act and the labor code. ${ }^{30}$ The first of these establishes that public sector jobs, posts or employment can only be created or suppressed by law. The wages act, which establishes the number of jobs and wages in each employment category, is approved annually along with the PGE act. Public sector hiring is mainly governed by the civil service act (which allows for job stability), but in some cases the labor code is also applied (which allows workers to be dismissed without due cause). Labor relations in DPIs and municipalities are governed by the labor code; therefore, they do not have job stability. In addition, procedures are not transparent for either hiring or promotion decisions. Scant use is made of aptitude tests, examinations, or public contests, as established by law, and there is significant variation in the wages paid by different public bodies for equivalent jobs.

14. In general, there are no ethical codes for public servants. Only the oversight body, the Office of the Comptroller General of the Republic (Corte de Cuentas de la República, $(C C R)$ ), has an ethical code, which was approved in 2001. Nonetheless, there are a number of laws and regulations that govern and punish inappropriate conduct by civil servants, such as the act on unlawful enrichment of public sector officials and employees, ${ }^{31}$ and a ban on employees of the DGII and the Directorate General of Customs accepting gifts of any kind. Monetary sanctions in the act on unlawful enrichment need to be updated; since the law dates from 1959 and sanctions are stated in nominal terms (for example the minimum fine is 100 colones or US\$11).

\footnotetext{
${ }^{29}$ Estimates of VAT evasion made by the DGII suggest that the average evasion rate fluctuated between 30 percent and 40 percent during 1996-98. El Salvador: Estimación de la Evasión Fiscal en IVA, 1998, the DGII, the MOF.

${ }^{30}$ The Civil Service Act (DL 507 issued in late 1961) was reformed by DL 678 in December 2001, and by DL 705 in January 2002; the latter contains regulations to make the benefits established by DL 678 effective. The reform carried out in 2001 to the Civil Service Act of 1961 established that if an official or employee is dismissed because his or her job is eliminated, the person in question will be entitled to severance pay based on a pre-established formula. This benefit was extended to employees working on permanent contracts.

${ }^{31}$ DL 2833 of 1959.
} 


\section{Public sector procurement}

15. The law on public procurement and contracting is clear and accessible, and widely applied despite still being unregulated. Recent legislation on administrative contracting $^{32}$ unifies several diverse laws; regulates procurement and contracting for civil works and goods and services by government institutions, including municipalities; and establishes a system of public competitive tendering for contract awards in excess of a preestablished amount (based on a multiple of the minimum wage). The law clearly identifies categories of persons that are ineligible to participate as suppliers (such as public officials and employees of the procuring institution, or their relatives; and municipal employees). It also establishes that competitive tenders must be published in the written press, bids opened publicly, and the results of bid awards made public. Application of the law has led to improvements in management capacity, better oversight of public procurement and contracting, and enhanced transparency and efficiency. Nonetheless, although the law should have been regulated within 90 days of its promulgation, to date this has not happened. In the meantime, the regulatory unit for public administration procurement and contracting, created by the procurement act, has issued three public handbooks to facilitate application of the law, which are readily accessible over the Internet. ${ }^{33}$ In addition, this unit's staff has given numerous talks throughout the country, instructing and disseminating the content of the law, and providing training in the use of computerized purchase records for the institutions covered by it.

\section{B. Public Availability of Information}

16. The PGE covers practically all fiscal activities of NFPS; and it is made public. ${ }^{34}$ In accordance with the LOAFI, it contains information on the fiscal activity of all central government primary units, nonentrepreneurial DPIs, and NFPEs. Nonetheless, as mentioned in Paragraph 11, it excludes the budgets of certain autonomous institutions, extraordinary

\footnotetext{
${ }^{32}$ The Public Administration Procurement and Contracting Act (DL 868 of April 2000).

${ }^{33}$ The three manuals known as "Procurement and Contracting Handbooks" are intended, respectively, for central government, municipalities, DPIs, and public enterprises. They can be downloaded from the MOF website http://www.mh.gob.sv.

${ }^{34}$ The PGE is presented annually in the document entitled "General State Budget Act," and is published on the MOF's website.
} 
resources, and special activity funds. ${ }^{35}$ It also gives no information on municipal budgets and includes only partial information on defense spending. ${ }^{36}$

\section{There is no legal requirement to publish periodic reports on budgetary} execution. The MOF prepares a variety of monthly ${ }^{37}$ and annual ${ }^{38}$ reports on budgetary execution, but they are not published. Biannual reports are also produced, but these are not submitted to the legislative assembly. Rating agencies get monthly reports on fiscal performance. The Constitution of the Republic requires government ministers to present the reports on the activities of public administration for the previous year to the legislative assembly. In addition, the MOF must submit the State Financial Management Report (Informe de Gestion Financiera del Estado) to the legislative assembly. This report contains a consolidation of the financial statements, economic performance, budgetary execution, and flow of funds for entities comprising the central NFPS (see Paragraph 32).

\section{There is, however, a commitment to publish fiscal data in accordance with the} requirements of the SDDS, ${ }^{39}$ and the $\mathrm{BCR}$ announces advance release-date calendars for the publication of economic and financial data. This includes monthly information on revenues, expenditure, budgetary balance, and funding sources - for central government, the rest of the general government sector, consolidated central government, nonfinancial public enterprises, and the nonfinancial public sector. In addition, the summary of economic and financial information agreed upon with the IMF is published on a monthly basis, in accordance with the SDDS. All this information is published punctually and is readily accessible through the BCR website.

\footnotetext{
${ }^{35}$ Extraordinary resources accounted for about 4 percent of the PGE in 2002. The proportion was much higher in 2001 when exceptional revenues and expenditure amounted to 16 percent and 11 percent of PGE income and expenditure, respectively, reflecting the larger flows of foreign funds in response to the earthquakes.

${ }^{36}$ National defense spending includes expenditures executed by the National Ministry of Defense, the Armed Forces Social Security Institute, and the Armed Forces Pharmaceutical Center. The two latter institutions have independent budgets, as mentioned in footnote 27, amounting to 40 percent of the National Ministry of Defense budget; these are approved by their own authorities and are not included in the PGE.

${ }^{37}$ Monthly reports on budgetary and public expenditure execution produced by the MOF include (1) "Budgetary Execution of the NFPS," (2) "Public Sector Investment Report;" and (3) "Progress Report on the NFPS

Investment Program." The latter provides very detailed information on the state of progress of programmed and executed investment, by institution, amount and source of funding, and activity sector. None of these monthly documents is published. Reports on the execution of the budget, execution of the investment program, status of the public debt, and revenue execution are sent to the Budgetary Oversight and Analysis Unit of the Finance and Special Budgetary Commission of the legislative assembly every month.

${ }^{38}$ Annual reports on budgetary execution are: (1) State Financial Management Report; (2) Monitoring and Evaluation Report on Central Government Budget Outturns; and (3) Progress Reports, produced by ministries. Only the second one is posted in the MOF website.

${ }^{39}$ Except for recording pension expenditure in the fiscal deficit.
} 
19. Budget documents do not compare the main fiscal aggregates with their outturns in previous fiscal years. Such information is brought together in the State Financial Management Report of 2001, for example, which shows central government budgetary execution during the five-year period 1997-2001, and its disaggregation, by economic sectors in terms of revenues and expenditure.

20. There is no published information on contingent liabilities, tax expenditure, or quasi-fiscal activities. Tax expenditures are negligible, but quasi-fiscal activities are significant in public financial institutions (see footnote 22). The provision of information on certain contingent liabilities, essentially those of public financial institutions, is impeded by the absence of relevant information in the corresponding financial statements.

21. Detailed information on public debt is published on a monthly basis, and data on financial assets are released annually. The level and composition of public debt, both domestic and external, is posted in the BCR website on a monthly basis. ${ }^{40}$ The information includes the balance of outstanding central government debt, both internal and external, with a breakdown among bonds, loans, and guaranteed debt; ${ }^{41}$ and the outstanding balance of external debt by debtor, creditor, and maturity. The annual State Financial Management Report includes the current status of long-term domestic public debt at year-end, and the direct external public debt of the central government, DPIs (entrepreneurial and otherwise), and of the consolidated public sector, all in net terms. The information also includes financial reports for central government, decentralized institutions, and the consolidated nonfinancial public sector, with data on financial assets broken down in terms of cash, advances, and financial investments.

22. No information is published on municipal budgets and borrowing. The only information included in the PGE is the percentage of current revenues that the state is legally required to transfer to the municipalities. Municipalities are obliged to use the general government accounting system for these funds, but, in practice, only a small proportion of them do so. ${ }^{42}$ As a constitutional requirement, ${ }^{43}$ municipal councils have to provide a detailed and documented account of the administration of their assets to the CCR, which in turn is responsible for subsequently auditing their budget execution. The main weakness in public finance statistics stems from the lack of information on budgetary execution among

\footnotetext{
${ }^{40}$ Debt data is provided in the BCR Monthly Statistical Bulletin, available at http://www.bcr.gob.sv, and in the Annual State Financial Management Report produced by the MOF.

${ }^{41}$ The guaranteed debt of NFPEs and the San Salvador City Hall, amounts to just over 2 percent of the total public debt.

${ }^{42}$ In late 2001, 33 percent of all municipalities (i.e., 85 out of 262) were using the government accounting system in varying degrees.

${ }^{43}$ Article 207 of the Constitution.
} 
local governments. Monthly NFPS budgetary execution reports from the MOF contain information on municipalities relating only to expenditures financed out of the monthly 6 percent transfer. The annual report contains sample based data on total municipal budgetary execution; and the BCR Quarterly Review publishes quarterly data on the budgetary execution of the general government and the NFPS, including sample-based municipal data.

\section{Open Budget Preparation, Execution, and Reporting}

\section{Preparation of the budget and budget documentation}

23. Budget documentation contains a declaration of medium-term fiscal policy goals as a framework for preparing the annual budget. There are no fiscal rules. Preparation of the budget, which is carried out in accordance with procedures, clearly set out in the norms and handbooks and following correct principles, tends to focus on the fiscal year timeframe. Medium-term macroeconomic and fiscal predictions are produced. The preamble to the budget document includes fiscal projections for the budget year and two additional years. ${ }^{44}$ However, no explanation is given on the assumptions and methods used. Nor does budgetary documentation include any analysis of the sustainability of fiscal policy. Fiscal policy objectives and priorities for the medium term are defined in the government program for the whole legislature. Though medium-term aggregated macrofiscal projections are prepared, no work has yet been done to prepare a quantitative and detailed medium-term expenditure framework, to serve as a basis for preparing the annual budget. The constitution and the LOAFI require the MOF to maintain the public finances in equilibrium, insofar as is compatible with the fulfillment of state goals. Nonetheless, it is not clear that this equilibrium refers exclusively to the operations of the NFPS.

\section{The PGE does not contain a comprehensive and integrated macroeconomic} framework or explanation of the assumptions used to prepare the budget. Formulation of the PGE is based on a macroeconomic framework that is prepared by the BCR but not included in budget documentation. The preamble to the budget bill contains only the growth and inflation targets used in its preparation; there is no explanation of the methods and assumptions used to make revenue forecasts, although these are made public in MOF publications.

25. Budget documents do not distinguish between existing and new policies, nor do they identify and quantify existing fiscal risks wherever possible. As mentioned above, no information is published on the contingent liabilities of the public sector, and there is no sensitivity analysis of the main fiscal aggregates with regard to potential changes in economic circumstances.

\footnotetext{
${ }^{44}$ Information on the deficit, primary saving, current saving, capital spending, and tax burden of the NFPS is provided in the preamble to the 2004 budget for the period 2004-06.
} 
26. The PGE does not contain any representative indicator of the overall fiscal policy stance. The budget document does not contain a summary table showing the budgetary balance of central government and the NFPS, based on its revenues and expenditure. The PGE contains summary tables for groups of institutions (primary central government, nonentrepreneurial DPIs, NFPEs) classified in terms of revenue and expenditure. Nonetheless, revenues are shown with a breakdown between current revenue, capital revenue, and financing (issuance of debt), and expenditures are classified between current expenditure, capital expenditure, and financial applications (debt amortization). The preamble to the draft budget law includes the fiscal deficit and current saving of the NFPS, together with the fiscal deficit, primary saving, and current saving of central governmentall expressed as percentages of GDP — but there is no explanation of how these figures are calculated.

27. Expenditure figures in the PGE are presented in gross terms and classified by institution, economic category, and sector, but there is no functional classification in line with international standards. The budget for each institution contains information on the mission of the entity, its expenditure priorities, expenditures classified by funding source, object of expenditure, economic classification, and budgetary unit, and staffing for each type of contract. Budgetary units, or budgetary programs, contain information on their general objectives and lines of work (activities), in addition to their purpose, their budgetary appropriation, economic classification, and staff endowments. The expenditure classification in seven management areas is an aggregation of the institutional classification, but not a substitute for a functional classification. ${ }^{45}$

\section{Preparation of the PGE is complemented by a physical and financial} programming document, containing physical and financial targets for each budgetary unit. This document, which does not actually accompany the PGE, contains detailed information for each budgetary entity and unit on the physical and financial targets of each line of work, and within these by specific activities. Physical programming is maintained in the SAFI to enable each institution to monitor its own budgetary management and the achievement of its targets; however, no report on the fulfillment of physical targets is provided to the legislative assembly or made public.

\section{Execution of the budget}

29. Internal control procedures are effective. Each budgeted entity is responsible for establishing an internal control system in accordance with technical rules issued by the CCR. The effectiveness of these systems is audited on a yearly basis by internal audit units. The latter report directly to the highest authority in each entity, who appoints the head of the audit

\footnotetext{
${ }^{45}$ The PGE draft is accompanied by the preamble of the budget bill, which provides summary information on its objectives, macroeconomic framework, general priorities, expenditure classification by entities, economic categories and management areas, and a summary table of the consolidated budget of the central NFPS.
} 
unit. Nonetheless, the heads of the internal audit units have full functional independence and can only be removed from their posts for legally established reasons, subject to prior report to the CCR. The audits carried out by these units are essentially financial, and their conclusions and recommendations are not made public.

30. The government accounting system allows for the production of full and reliable intra-year reports on payment arrears. The SAFI accounting system records all stages of the expenditure process and generates information on foreign aid and payment arrears, which are not a problem in El Salvador. At the present time, SAFI is not operational in DPIs or local governments.

31. Tax administration is legally protected from political interference. Tax administration is the responsibility of the DGII and the Directorate General of Customs, both of which are attached to the MOF. The first is legally an independent technical body, ${ }^{46}$ so its actions or resolutions are not controlled or subject to interference by any state organization.

\section{Reporting}

32. Final audited accounts are made available within seven months of the close of the fiscal year. The government submits the State Financial Management Report to the legislative assembly within three months following the end of each fiscal year (see Paragraph 17). The CCR has four months to scrutinize and audit the accounts. This report also provides information on all the extrabudgetary activities.

\section{Assurances of Integrity}

\section{Data quality standards}

33. The PGE is not a very good indicator of the budget as finally executed. Although revenue forecasts are quite reliable (the rate of execution of the modified central government revenue budget is adequate, averaging 95 percent for the last seven years), execution of the expenditure budget is weak ( 90 percent of total expenditure and under 75 percent of investment expenditure). Any supplementary budgets have to be approved by the legislature and must specify expenditure items with their corresponding funding sources or increases in estimated revenues. Supplementary budgets represented on average 7 percent of the initial PGE during 1998-2000, and 18 percent in 2001 as a result of reconstruction expenditure. ${ }^{47}$

34. Neither the budget nor the final accounts include a declaration of accounting policies. Accounting principles and policies are contained in the LOAFI and in the 2001

\footnotetext{
${ }^{46}$ Organic law of the DGII, Article 2.

47 "Evaluation of Central Government Budgetary Outturns as of December 31, 2001."
} 
Government Accounting System Manual (Manual del Sistema de Contabilidad Gubernamental 2001), but this is not published. The PGE and the final accounts of the NFPS are recorded on an accrual basis. The MOF approves the principles and general rules of government accounting (accounting policy and its specific rules, along with the accounts plan and the technical procedures to be applied) and modifications as necessary.

\section{The SAFI allows for routine and timely reconciliation of public accounts.}

Reconciliations relate to expenditures made with budgetary appropriations, accounting data on revenues and payments with debits and credits to bank accounts, and both above- and below-the-line data.

36. The BCR prepares most of the country's economic statistics. The organic law of the National Statistical Service of El Salvador is antiquated (it dates from 1955) and the Directorate General of Statistics and Censuses attached to the Ministry of Economic Affairs is largely inactive for lack of funding. In these circumstances, and given that the country subscribes to the SDDS, the BCR has taken the initiative of investigating, collecting, compiling, tabulating, analyzing, publishing, and distributing economic and fiscal information.

\section{Independent scrutiny}

37. The CCR carries out the external audit of the public sector, exercises jurisdictional functions, and directs, regulates, and evaluates the internal control and internal audit systems. The first two of these functions are established in the constitution and the third in its regulatory law. ${ }^{48}$ The CCR fulfills its jurisdictional role of determining and sanctioning administrative and financial responsibilities in the administration of public funds, through Chambers of First and Second Instance. ${ }^{49}$ Exercise of these functions is not current practice in most countries nowadays, given principles of division of powers and jurisdictional unity. Also it is unusual to find no clear distinction between the internal and external audit functions. According to its charter, the CCR is the governing body of the national public management oversight and audit system, which encompasses internal control

\footnotetext{
${ }^{48}$ Articles 195-199 of the Constitution; the Act Concerning the Comptroller General of the Republic (Decree 438 of August 31, 1995); Functional Organic Regulation of the Office of the Comptroller General of the Republic (Decree 12 of June 14, 1999); Regulation to Define Responsibilities (Decree 6 of May 21, 1996); and Regulation on the Exercise of Jurisdictional Functions (Decree 7 of June 17, 1997). These laws can all be found on the CCR website: http://www.cortedecuentas.gob.sv.

${ }^{49}$ Each Chamber of First Instance, consisting of two judges, issues initial rulings on financial responsibilities in accounts proceedings (juicios de cuentas). Their sentences can be appealed before the Chamber of Second Instance, consisting of the president of the CCR and two judges.
} 
and internal audit unit of each entity and the ex-post external control carried out by the $\mathrm{CCR}^{50}$

38. The CCR is independent of the executive branch, as established in the constitution. The president and the two judges of the Chamber of Second Instance are appointed by the legislative assembly and can only be removed by that body for legally justified reasons. The CCR is independent in terms of functions, management, and budget; and it prepares its own draft budget which it submits to the government for inclusion in the PGE. Any adjustments that the assembly wishes to make are done in consultation with the CCR and the MOF. In exercising its external audit functions, CCR staff have unfettered access to all information and documentation they may need for carrying out their work. The mandate of the president and judges lasts for just three years, subject to reelection. ${ }^{51}$

39. The legislative assembly does not monitor external audit reports, the conclusions and recommendations of which are not published. The law regulates the types of audit the CCR can carry out; they cover compliance, financial, and operational issues. Its technical capacity to conduct these audits is modest, and it has made a major effort over the last three years to bring itself up to date on the auditing of central government bodies. Legally, internal and external audit reports are public documents, but there is no obligation to publish their conclusions and recommendations, and they are not published. ${ }^{52}$ Nor does the legislative assembly review these reports; by law, audit reports are sent to the assembly only if the latter requests them. Audit recommendations are legally binding, and compliance is verified in each subsequent internal and external audit report.

\section{IMF STAFF COMMENTARY}

\section{El Salvador complies with many of the norms of the Code of Good Practices on Fiscal Transparency.}

- Definition of the government sector is consistent with the GFS Manual.

\footnotetext{
${ }^{50}$ The CCR is responsible for its development, regulation, and evaluation. As such, it issues basic rules on internal control and guidelines for conducting public audits; it receives audit plans from all entities and a copy of all audit reports filed. As mentioned above, no employee of the internal audit units of these entities can be removed from their post without CCR authorization. The dual dependency of these units, which is difficult to specify, blurs the clear separation of functions that should exist between the legislative and executive powers in terms of external and internal oversight responsibilities.

${ }^{51}$ Neither the constitution nor the law regulates incompatibilities with respect to the posts of CCR president or judge.

${ }^{52}$ According to the CCR, these reports are public in the sense that anyone can have access to them on request.
} 
- $\quad$ Relations between the government and NFPEs are clear, and privatizations are subject to independent audits.

- $\quad$ The regulatory framework for fiscal management is complete, and is complemented by abundant manuals and instructions to facilitate the preparation and execution of the PGE.

- $\quad$ The coverage of the PGE and fiscal reports is quite complete. Extrabudgetary activities are consolidated with budgetary activities and published at the end of each fiscal year.

- $\quad$ El Salvador subscribes to the SDDS and supplies information for the Fund's GFS on a timely basis.

- Full information is disseminated on the level and composition of the debt of the central NFPS.

- $\quad$ Budgetary data are presented in gross form and classified by institution, economic categories, and object of expenditure.

- $\quad$ The SAFI contains an integrated accounting system of general scope, which makes it possible to evaluate payment arrears, generate timely reports on budgetary execution and reconcile monetary and accounting data on a routine basis.

- $\quad$ The legislative assembly receives final accounts audited by the CCR within one year of the end of the fiscal year.

- Internal control systems exist; and the internal audit units monitor their effectiveness each year.

- $\quad$ The new law on public procurements has introduced important transparency requirements in public contracting.

\section{Nonetheless, EI Salvador needs to make progress on a number of important} aspects of the code on fiscal transparency. Improvements in the coverage and presentation of the PGE and periodic budgetary execution reports, as well as the dissemination of fiscal data can be addressed immediately. Additional changes in these and other areas are likely to need more time either because the necessary information is not yet available, they may require regulatory changes, or the design and implementation of the change itself will take time. In particular, it would be helpful to generalize the SAFI system, clearly distinguish the fiscal roles of central government and local authorities, expand the content of budgetary documentation, clarify and strengthen internal and external audit systems, and improve budget preparation. 


\section{The authorities could swiftly make significant changes on fiscal transparency in the following areas:}

- The coverage and presentation of the PGE could be enhanced by including:

fiscal activities currently excluded from the PGE, referred to in footnote 26 , to enable the budget document to contain information on the entire fiscal activity of all NFPS institutions, while still maintaining exemption from legislative approval for the budgets of certain autonomous bodies whose founding charters so require;

a consolidated central government budget consistent with GFS, in addition to the consolidated NFPS budget;

a number of summary tables showing revenues, expenditure, budgetary balance and sources of financing of the NFPS, central government and each of the groups of institutions comprising it, to make it easy to identify the contribution of each of these groups to the overall balance, and their budget constraints;

annexes containing medium-term fiscal policy goals, a comprehensive and integrated macroeconomic framework, medium-term fiscal policy objectives and priorities, and an explanation of the methods and assumptions used to calculate macroeconomic and revenue forecasts;

a comparison between the main budgetary aggregates and their outturns in previous fiscal years;

clear distinction between current policies and new ones introduced by the budget; and

$>\quad$ the physical and financial programming document containing physical and financial targets for the activities of budgetary units.

- $\quad$ Expand the dissemination of fiscal data. The authorities are already in a position to disseminate the following information:

monthly reports on PGE execution and at least a quarterly report on compliance with physical targets and public investment execution, distinguishing between central government and the rest of the NFPS;

State Financial Management Reports and audit reports prepared by the CCR; Monitoring and Evaluation Reports on Central Government Budgetary Outturns; and Activities Reports of the different public sector entities; and 
accounting principles and rules and general accounts plan.

43. Generalization of SAFI to the DPIs and local governments should be a major priority, given its relevance for additional progress in other areas. In particular, this will make it possible to achieve:

- more effective preparation of the budget, and stricter control of its execution,

- $\quad$ more reliable and timely information on central government as a whole; and

- better information on the execution of municipal budgets and, in particular, on the use of FODES resources. On the first point, while seeking a more stable solution, the sampling system currently used could be improved.

44. It is also important to clarify the distribution of functions between levels of government, in particular, their roles in terms of expenditure and taxes, and to redefine the borrowing faculties of municipalities and set limits on this.

\section{Budgetary documentation could be improved by providing:}

- $\quad$ a statement which identifies and quantifies quasi-fiscal activities carried out by NFPEs and public financial institutions to assess the burden they place on the entities that carry them out and on the overall asset position of the public sector (this information should also be provided with the accounting statements of the entities that carry them out);

- a statement on fiscal risks, including contingent liabilities and the effects of changes in economic parameters on fiscal aggregates; and

- $\quad$ an estimate of tax expenditures, making it possible in each case to identify, along with direct budgetary expenditure, the indirect expenditure deriving from preferential tax treatments.

46. It would be useful to redefine and strengthen control systems and publicize their actions, through:

- $\quad$ establishing a better delineation of internal and external oversight functions, maintaining the necessary coordination between these and CCR functions in supervising internal oversight systems and internal audit, but avoiding the dual dependency of internal audit units;

- $\quad$ carrying out performance audits;

- $\quad$ improving CCR staff endowments and information technology resources; 
- $\quad$ publishing the conclusions and recommendations of audit reports on effective monitoring and application; and

- transferring jurisdictional functions from the CCR to the ordinary courts.

47. Preparation and presentation of the budget could benefit by:

- developing a medium-term public expenditure scenario, which would facilitate up-todate estimates of current policies for a 3-4 year period. This is an instrument that has proven very useful for more disciplined preparation of the budget, improving resource allocation in accordance with the government's political priorities, and introducing efficiency in resource use; and

- improving the public expenditure classifications: in particular, it is important for the authorities to introduce a functional classification that is consistent with international standards, and consider the extent to which the classification of expenditure by budgetary units is a good substitute for a program-based classification.

48. Lastly, the authorities could improve the transparency of the legal framework by:

- $\quad$ introducing a legal requirement for all new regulations in the private sector to be submitted to a hearing by affected parties, together with an estimation of impact, benefits and costs, and periodic evaluation to judge the convenience of maintaining, modifying or eliminating them;

- $\quad$ ensuring more transparent application of the civil service act;

- $\quad$ developing the public procurement act from the regulatory standpoint; and

- $\quad$ making the dissemination of fiscal information a legal obligation of the government. 